\title{
Effect of neuroserpin in a neonatal hypoxic-ischemic injury model ex vivo
}

\author{
Jiao Ma1, 3 , Dan Yu' 2, 3, Yu Tong1, 3, Meng Mao', 2, 3 \\ ${ }^{1}$ Department of Pediatrics, West China Second University Hospital, Sichuan University, Chengdu, PR China \\ 2 Key Laboratory of Obstetric \& Gynecologic and Pediatric Diseases and Birth Defects of Ministry of Education, Chengdu, PR China \\ ${ }^{3}$ Laboratory of Early Developmental and Injuries, West China Institutes for Woman and Children's Health, West China Second University Hospital, Sichuan University, \\ Chengdu, PR China
}

\section{ABSTRACT}

Hypoxia-ischemia (HI) occurring in immature brains stimulates the expression of tissue-type plasminogen activator (tPA). Neuroserpin is a selected inhibitor of tPA in the central nerves system. However, the role that neuroserpin plays and the possible mechanisms involved during neonatal HI are poorly defined. In this study, an oxygen-glucose deprivation and reoxygenation (OGD/R) model was generated with cultured rat cortical neurons mimicking neonatal HI injury ex vivo, and an acute neuronal excitatory injury was induced by exposure to a high concentration of N-methyl-D-aspartic acid (NMDA). Cells received either neuroserpin or MK-801, an antagonist of the NMDA receptor, during OGD/R, and were incubated with or without neuroserpin after NMDA exposure. Cell viability and morphology were detected by a Cell Counting Kit-8 and immunohistochemical staining, respectively. TPA expression and activity were also assessed. We found that MK-801 alleviated injuries induced by OGD/R, suggesting an excitatory damage involvement. Neuroserpin provided a dosedependent neuroprotective effect in both OGD/R and acute excitatory injuries by inhibiting the activity of tPA, without affecting neuronal tPA expression. Neuroserpin protected neurons against OGD/R even after a delayed administration of $3 \mathrm{~h}$. Collectively, our data indicate that neuroserpin protects neurons against OGD/R. mainly by inhibiting tPA-mediated acute neuronal excitotoxicity.

Key terms: excitotoxicity, hypoxia-ischemia, neuroserpin, N-methyl-D-aspartic, tissue-type plasminogen activator.

\section{INTRODUCTION}

Tissue-type plasminogen activator (tPA), a serine proteinase cleaving plasminogen into plasmin, is well known as a thrombolytic enzyme in the intravascular space (Collen, 2001). However, tPA is also expressed in the central nervous system (CNS) and displays both physiological and pathological activity (Benarroch, 2007). Neuroserpin (NSP), an axonally secreted serine protease inhibitor (Osterwalder et al., 1996), is a selective inhibitor of tPA in the CNS. Both of these proteins are associated with neuronal activity and stimulated to release by neuronal depolarization (Qian et al., 1993; Berger et al., 1999).

Studies propose that neuroserpin functions as a neuroprotective factor by eliminating the deleterious effects of tPA in some pathological conditions. The genetic knockout of tPA or administration of neuroserpin has shown better results in ischemic stroke models (Wang et al., 1998; Zhang et al., 2002; Yepes et al., 2000). During the course of cerebral ischemia, endogenous neuroserpin increases and then blocks microglial activation, decreases the number of apoptotic cells, preserves the integrity of blood brain barrier (BBB) and attenuates tPA-mediated inflammation (Yepes and Lawrence, 2004; Rodríguez-Gonzáez et al., 2011). Furthermore, tPA has been indicated to enhance N-methyl-D-aspartic acid (NMDA) receptor-mediated excitatory neuronal death, and tPAdeficient mice show a dramatic resistance to excitotoxicity (Nicole et al., 2001; Tsirka et al., 1995). Additionally, neuroserpin protects neurons against low concentration NDMA-induced chronic excitotoxicity both in vitro and in vivo (Lebeurrier et al., 2005). A negative correlation between a decrease of serum neuroserpin level and an increase of glutamate has been found in adult ischemic stroke patients recently (Rodríguez-González et al., 2011).

Although the role of neuroserpin in the adult ischemic stroke model has already been investigated, its effect in neonatal hypoxia-ischemia (HI) injury as well as in acute excitotoxicity has not been revealed. Unlike adult brains, HI only transiently impairs blood perfusion in newborn (Mujsce et al., 1990; Adhami et al., 2008). Reperfusion is accompanied by increased glucose levels, which has been shown to be detrimental (Sheldon et al., 1992), and excessive oxygen and free radicals, producing further brain injury (Harukuni and Bhardwaj, 2006). Based on this evidence, we used an oxygenglucose deprivation and reoxygenation (OGD/R) model to mimic neonatal HI injury ex vivo. An acute neuronal excitatory injury model was generated by exposure to high NMDA concentration. We tested the hypothesis that neuroserpin would display neuroprotective effects by restraining tPAmediated acute neuroexcitotoxicity in neonatal $\mathrm{HI}$.

Abbreviations: BBB: blood brain barrier; BSA: bovine serum albumin; CCK-8: Cell Counting Kit-8; CNS: central nervous system; DMEM: Dulbecco's modified Eagle medium; EAAs: excitatory amino acids; ELISA: enzyme-linked immunosorbent assay; FCS: fetal calf serum; HI: hypoxia-ischemia; HIE: hypoxic-ischemic encephalopathy; LTP: long-term potentiation; MAP2: microtubule-associated protein 2; NB: neurobasal medium; NMDA: N-methyl-D-aspartic; NSP: neuroserpin; OGD/R: oxygen-glucose deprivation and reoxygenation; PAI1: plasminogen activator inhibitor-1; QRT-PCR: Quantitative real-time reverse-transcriptase Polymerase Chain Reaction; tPA: tissue-type plasminogen activator.

Corresponding authors: Meng Mao, West China Second University Hospital, Sichuan University, Chengdu 610041, PR China, Tel: 13608088613 , Fax: +86 28 87461751, E-mail address: dffmmao@126.com, Dan Yu, West China Second University Hospital, Sichuan University, Chengdu 610041, PR China, Tel: 15928623580 , Fax: +86 28 85501319, E-mail address: yd540@126.com

Received: January 19, 2012. In Revised form: August 27, 2012. Accepted: August 30, 2012 


\section{METHODS}

\section{Material}

NMDA and poly-D-lysine were from Sigma-Aldrich ((St. Louis, MO, USA). Dulbecco's modified Eagle medium (DMEM), neurobasal medium (NB), B27, fetal calf serum (FCS), glutaMax and penicillin/streptomycin were obtained from Gibco (GrandIsland, NY, USA). Human recombinant neuroserpin was bought from PeproTech (Rocky Hill, NJ, USA). The Cell Counting Kit-8 (CCK-8) was from Dojindo (Dojindo, Kumamoto, Japan). Primary antibody, mouse MAP-2 antibody, was from Abcam (Abcom, Cambridge, UK) and a FITC-conjugated rabbit anti-mouse IgG is a product of Santa Cruz Biotechnology (Santa Cruz, CA, USA). All the reagents for QRT-PCR were from BioRad (Biorad Laboratories, Hercules, CA).

Animals and primary culture of rat cortical neurons

All animal procedures were approved by the Sichuan University Committee on Animal Research. Pregnant SpragueDawley rats were supplied by the Experimental Animal Center of Sichuan University. Each test was repeated 3 times.

Cortical neurons were prepared from the brains of rat embryos (E15-16) as described previously (Zhang et al., 2009). Cells were planted on plates coated with $0.1 \mathrm{mg} / \mathrm{ml}$ poly-Dlysine in a DMEM supplement containing $10 \%$ FCS, $2 \mathrm{mM}$ glutaMax, $100 \mathrm{U} / \mathrm{mL}$ penicillin and $100 \mathrm{mg} / \mathrm{mL}$ streptomycin. The cultures were incubated in a humidified atmosphere of $5 \%$ $\mathrm{CO}_{2}$, maintained $37{ }^{\circ} \mathrm{C}$ for 4 hours, then the DMEM supplement was replaced with neurobasal medium with $2 \%$ B27 and $2 \mathrm{mM}$ glutaMax, $100 \mathrm{U} / \mathrm{mL}$ penicillin and $100 \mathrm{mg} / \mathrm{mL}$ streptomycin. Half medium replacement was performed every 3 days, and the following experiments were implemented on in vitro days 7-10.

Oxygen-glucose deprivation/ reoxygenation $(O G D / R)$ and treatment

To initiate the HI condition in vitro, oxygen-glucose deprivation was performed as previously described (Zhang et al., 2009). Briefly, the cells were washed three times with glucose-free medium (125 mM NaCl, $2.8 \mathrm{mM} \mathrm{KCl}, 1.5 \mathrm{mM} \mathrm{MgCl}_{2}, 0.05 \mathrm{mM}$ $\mathrm{MgSO}_{4}, 2 \mathrm{mM} \mathrm{CaCl}, 0.83 \mathrm{mM} \mathrm{NaH}{ }_{2} \mathrm{PO}_{4}, 24 \mathrm{mM} \mathrm{NaHCO}, 2$ mM HEPES) prior to oxygen removal and placed in an anaerobic chamber containing $95 \%$ nitrogen and $5 \% \mathrm{CO}_{2}$ at $37{ }^{\circ} \mathrm{C}$ for $2 \mathrm{~h}$ in the same glucose-free medium. To generate a reoxygenation injury, cells were then placed in the original neurobasal medium and returned to the incubator under normoxic conditions.

To study the effect of neuroserpin on OGD/R neurons, progressive concentrations of neuroserpin ( 0 to $1.2 \mu \mathrm{mol} / \mathrm{L}$ ) were added to normal neurobasal medium immediately after OGD (this time point is referred to as reoxygenation $0 \mathrm{~h}, \mathrm{R} 0 \mathrm{~h}$ ). To explore the window of neuroserpin treatment, $900 \mathrm{nmol} / \mathrm{L}$ neuroserpin was administrated at different time points (R0h, R1h, R2h, R3h, R4h).

To explore the excitatory effect induced by OGD/R, a subset of neurons was incubated with MK-801 10 $\mu \mathrm{mol} / \mathrm{L}$ at R0h. All samples were collected at R24h.

\section{Effects of neuroserpin and MK-801 on normal neurons}

To test the effects of neuroserpin and MK-801 on neurons, $900 \mathrm{nmol} / \mathrm{L}$ neuroserpin and $10 \mu \mathrm{mol} / \mathrm{L}$ MK-801 were added to neurons without OGD/R injury. Application of normal saline (NS) provided controls. Samples were harvested for the CCK-8 test at $0 \mathrm{~h}, 4 \mathrm{~h}, 8 \mathrm{~h}, 12 \mathrm{~h}$ and $24 \mathrm{~h}$ after treatment.

\section{Excitotoxic neuronal injury and neuroserpin treatment}

A quickly-triggered excitotoxic insult was induced in the cultured cortical neurons by $2 \mathrm{~h}$ exposure to 0 to $800 \mu \mathrm{mol} / \mathrm{L}$ NMDA; then neurons were cultured in original neurobasal medium. Neuroserpin $900 \mathrm{nmol} / \mathrm{L}$ was added to neurobasal medium after $2 \mathrm{~h}$ exposure to $600 \mu \mathrm{mol} / \mathrm{L}$ NMDA. Samples were harvested $24 \mathrm{~h}$ later.

\section{Neuronal viability assay}

For quantitative analysis of cell viability, the CCK-8 test was used, critically following the manufacturer's instructions. Briefly, at harvest time $10 \mu \mathrm{L}$ CCK- 8 solution was added to each well; the total volume of culture medium was $100 \mu \mathrm{L}$ per well. After incubation at $37^{\circ} \mathrm{C}$ for $1 \mathrm{~h}$ in a humidified $\mathrm{CO}_{2}$ incubator, absorbance at $540 \mathrm{~nm}$ was monitored with the Model 680 microplate reader (Bio-Rad). The values were used to calculate cell viability by setting the normoxic control as $100 \%$.

\section{Immunocytochemistry}

Immunocytochemistry was performed $24 \mathrm{~h}$ after OGD/R and NMDA exposure (Zhang et al., 2009). Neuronal cultures were fixed with $4 \%$ paraformaldehyde for $10 \mathrm{~min}$ at $4{ }^{\circ} \mathrm{C}$, washed with PBS and incubated for $30 \mathrm{~min}$ at $4{ }^{\circ} \mathrm{C}$ in the presence of PBS containing $0.3 \%$ Triton-X100 and $1 \%$ bovine serum albumin (BSA). Primary antibody, mouse MAP-2 antibody (1:250), was incubated overnight at $4{ }^{\circ} \mathrm{C}$ and then washed 3 times with PBS containing 0.1\% Tween-20 (PBST). Cells were incubated for $1 \mathrm{~h}$ with a FITC-conjugated rabbit anti-mouse IgG (1:200). Cultures incubated without primary antibody were used as negative controls. Images were observed using a light microscope (Leica). Eight images were randomly selected from one slice and each group was observed on 3 independent slices. MAP2 expression was analyzed by NIS-Elements AR 3.00, SP7 (Build 547), Imaging Software, setting normal MAP2 expression as 1 .

Quantitative real-time reverse-transcriptase PCR

Total RNA strands were extracted from cultured cells using the iScript ${ }^{\mathrm{TM}}$ RT-qPCR Sample Preparation Reagent. RNA (1 $\left.\mu \mathrm{g}\right)$ was reverse transcribed using an iScript ${ }^{\mathrm{TM}} \mathrm{cDNA}$ Synthesis Kit. The following primer sequences were used: (a) tPA: sense primer 5'-GGCCAAATGCCATCAAGCT-3', antisense primer 5'-CGTGGTATACTTCCCTGCCTTAAA -3'; (b) GAPDH : sense primer 5'-CAAGTTCAACGGCACAGTCAA -3', antisense primer 5'-TGGTGAAGACGCCAGTAGACTC -3'.; Two negative controls were performed: samples without reverse transcription, and RNase-free water instead of cDNA. Assays were run using SsoFast ${ }^{\mathrm{TM}}$ EvaGreen Supermix and the iCycler iQ real-time PCR detection system. Amplification conditions were: $95{ }^{\circ} \mathrm{C}$ for 2 minutes followed by 40 cycles at $95{ }^{\circ} \mathrm{C}$ for 1 second and at $62.5^{\circ} \mathrm{C}$ for 7 seconds. The levels of expression of the gene of interest were computed as follows: relative mRNA expression $=2^{-(C t \text { of gene of interest })}$, where $C t$ is the threshold-cycle value. They were also computed with respect to the mRNA 
expression level of the reference gene transcript using the formula:

Relative mRNA expression $=2^{-(C t \text { of gene of interest }-C t \text { of gene of reference) }}$

tPA activity assay

tPA activity in the cultured medium was detected by enzyme-linked immunosorbent assay (ELISA) following the manufacturer's instructions (NovoNordisk, Bagsvaerd, Denmark).

Statistical Analysis

Data are presented as mean \pm standard deviation (SD). Student's $t$ test was used to compare between 2 groups. ANOVA with Fisher post hoc test was used for comparing more than 2 groups. A value of $P<0.05$ was defined as statistically significant.

\section{RESULTS}

Neuroserpin protects neurons against $O G D / R$ injury

Figure 1B shows that exposure to OGD / R conditions decreased neuronal viability to $24.32 \pm 3.96 \%$. The treatment with neuroserpin produced a concentration-dependent increase in neuronal viability, $36.82 \pm 3.61 \%$ when administered at $900 \mathrm{nmol} / \mathrm{L}, \mathrm{p}<0.05$. Normal saline (NS) showed no protective effect on OGD/R neurons when neuroserpin was not present. This indicated that the neuroprotective effect of neuroserpin in OGD/R condition was independent of NS.

The administration of $900 \mathrm{nmol} / \mathrm{L}$ neuroserpin to normoxic neurons showed no effect on cell viability compared to the normal saline-treated group. Cell viability was $93.67 \pm 1.22 \%$ (neuroserpin treated group) and $91.67 \pm 2.02 \%$ (normal salinetreated group), respectively, after 24 hours exposure, $\mathrm{p}=0.27$ (Fig. 1A). This indicated that neuroserpin had no proliferous or detrimental effect under normal conditions.

We also found that treatment with $900 \mathrm{nmol} / \mathrm{L}$ neuroserpin within $3 \mathrm{~h}$ after OGD/R provided efficient neuroprotection (Fig. 1C). Cell morphological changes were observed by MAP2 immunofluorescence (Fig. 2A). OGD/R induced a breakdown of neuritic networks with a decreased MAP2 expression. However, treatment with $900 \mathrm{nmol} / \mathrm{L}$ neuroserpin clearly preserved neurons with a lesser extent of neurite fragmentation (Fig. 2).

Neuroserpin protects neurons against NMDA-induced acute excitotoxicity

The 2h-exposure to NMDA caused a dose-dependent decrease in neuronal viability (Fig. 3A). In this acute neuroexcitotoxic state induced by $600 \mu \mathrm{mol} / \mathrm{L} \mathrm{NMDA}, 900 \mathrm{nmol} / \mathrm{mL}$ neuroserpin promoted neuronal viability from $56.67 \pm 8.7 \%$ to $89 \pm 7.5 \%$ (Fig. 3B). Cell morphological changes were also detected by MAP2 immunofluorescence (Fig. 2A). We found that NMDA exposure led to a retraction of neurites, and that administration of neuroserpin protected neurons efficiently.

\section{NMDAR-mediated neuronal excitotoxicity in $O G D / R$}

The incubation of $10 \mu \mathrm{mol} / \mathrm{L}$ MK-801 with normoxic neurons showed no proliferous or damage effects during a $24 \mathrm{~h}$ timecourse compared to the saline treated group. Cell viability was $91.2 \pm 2.33 \%$ (MK-801 treated group) and $91.67 \pm 2.02 \%$ (normal saline-treated group), respectively, after 24 hours exposure, $\mathrm{p}=0.49$ (Fig. 1A). However, MK-801 raised cell viability from $25.23 \pm 3.95 \%$ to $33.57 \pm 3.86 \%$ during OGD/R (Fig. $1 C)$. These results indicate that neuronal excitatory damage constitutes the total neuronal injury caused by $2 \mathrm{~h}$ OGD and $24 \mathrm{~h}$ reoxygenation.

Effects of neuroserpin on $t P A$ expression and activity in $O G D / R$ injury and NMDA-induced acute excitotoxicity

tPA mRNA expression and enzyme activity were detected by quantitative Real-time PCR (QRT-PCR) and ELISA, respectively. We found that tPA mRNA and enzyme activity was dramatically increased within $4 \mathrm{~h}$ after OGD/R and maintained a high level at R24h. Although neuroserpin had no effect on mRNA expression of tPA (Fig. 4A), it inhibited tPA activity efficiently (Fig. 4B).

Similarly, acute induction of excitotoxicity raised the mRNA expression of tPA and elevated tPA activity. Neuroserpin
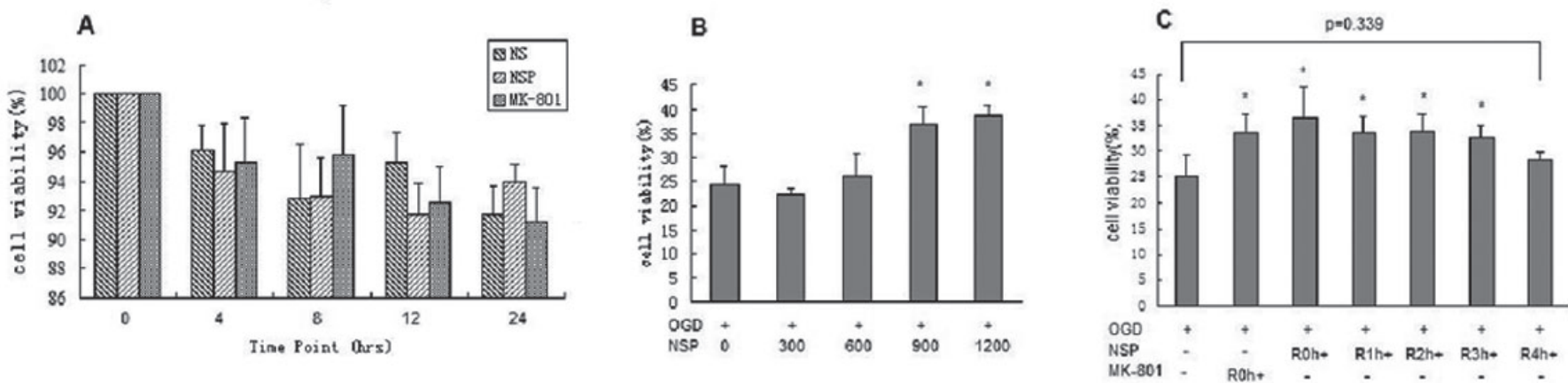

Figure 1. The neuroprotective effects of neuroserpin and MK-801 against OGD/R insult detected by CCK-8. (A) Administration of neuroserpin and MK-801 to normoxic neurons showed no increase in cell viability compared with the normal saline (NS) treated group. (B) Neuroserpin increased the cell viability in a concentration-dependent way, 900nmol/L neuroserpin protected neurons efficiently. (C) $900 \mathrm{nmol} / \mathrm{L}$ neuroserpin protected neurons with a delayed administration of 3 hours after OGD/R and $10 \mu \mathrm{mol} / \mathrm{L}$ MK-801 also increased cell viability. Normoxic cells were defined as control group. Mean cell viability was calculated by setting the control group as $100 \%$, and represented as mean \pm SD. ${ }^{*} \mathrm{P}<0.05$ compared to the control group. Each result was repeated 3 times. 
A

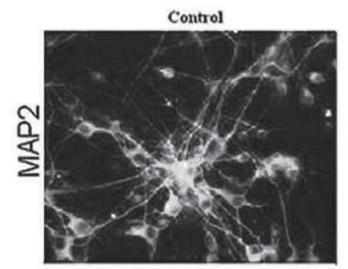

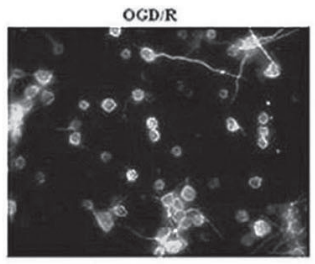

NMDA

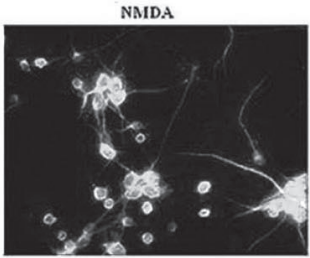

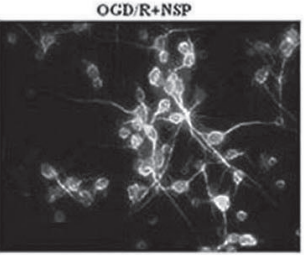

NMDA+NSP

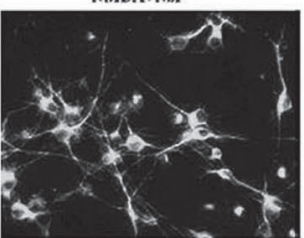

B

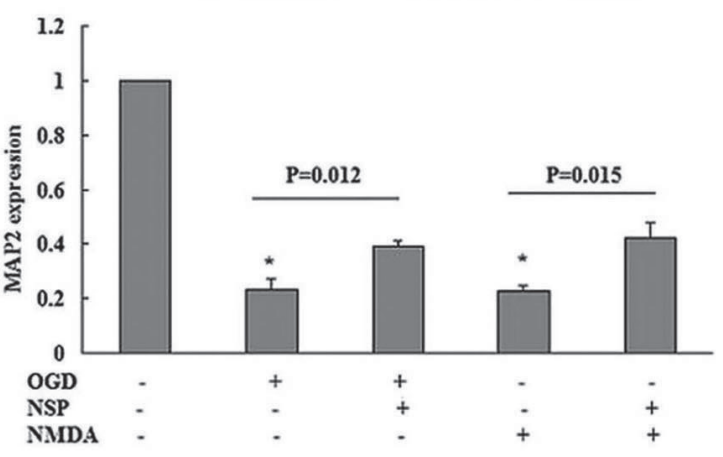

Figure 2. MAP-2 detection by immunofluorescence. (A) Cell morphological change was observed by MAP2 immunostaining. Normoxic cells were defined as the control group. Bar=40 $\mu \mathrm{m}$. (B) MAP2 expression was analyzed by NIS-Elements AR 3.00, SP7 (Build 547), Imaging Software, setting the control group MAP2 expression as 1 . Eight images were randomly selected on one slice and each group was observed on 3 independent slices.
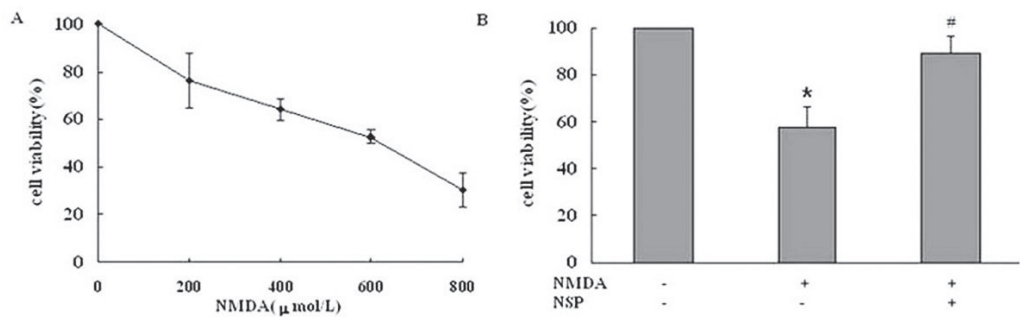

Figure 3. Protective effects of neuroserpin against NMDA-induced acute excitatory injury detected by CCK-8 test. (A) NMDA induced a dose-related decrease in cell viability. (B) $900 \mathrm{nmol} / \mathrm{L}$ neuroserpin protected neurons against acute excitatory injury induced by $2 \mathrm{~h}$-exposure to $600 \mu \mathrm{mol} / \mathrm{L}$ NMDA. Untreated cells were taken as the control group. Mean cell viability was calculated by setting the control group as $100 \%$, and represented as mean \pm SD. ${ }^{*} \mathrm{P}<0.05$ compared to the control group, ${ }^{\#} \mathrm{P}<0.05$ compared to the NMDA-treated group.
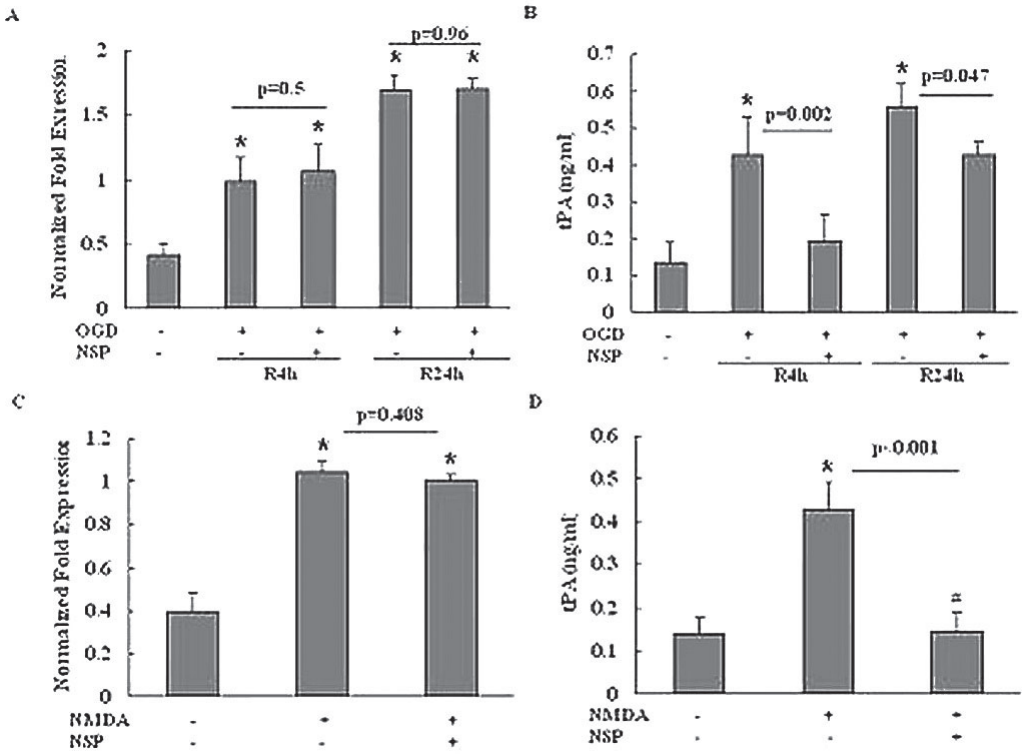

Figure 4. The regulation of tPA mRNA expression and enzyme activity. QRT-PCR showed tPA mRNA expression in the OGD/R model (A) and NMDA-induced acute excitatory injury models (C). ELISA revealed the enzyme activity of tPA in the culture medium in OGD/R model (B) and NMDA-induced acute excitatory injury models (D). Neurons in normal condition were taken as the control group. ${ }^{*} \mathrm{P}<0.05$ compared to the control group. ${ }^{\#} \mathrm{P}<0.001$ compared with neurons treated with NMDA alone. Each observation was repeated 3 times. 
dramatically inhibited the enzyme activity of tPA but failed to affect the neuronal expression of tPA (Fig. 4C and 4D).

\section{DISCUSSION}

In the present study, we demonstrate that neuroserpin protects neurons against $\mathrm{HI}$, mainly depending on the regulation of tPA-mediated acute excitotoxicity, even with a delayed administration of $3 \mathrm{~h}$ after the $\mathrm{HI}$ insult.

Perinatal HI brain damage is a leading cause of early mortality and permanent neurological morbidity in infants (Ferriero, 2005). A growing body of evidence suggests that the PA system, including tPA, plays a detrimental role in $\mathrm{HI}$ events (Wang et al., 1998; Adhami et al., 2008; Yang et al., 2009). Recently, the involvement of tPA has been demonstrated in a rat neonatal hypoxic-ischemic encephalopathy (HIE) model ((Adhami et al., 2008; Yang et al., 2009). The use of plasminogen activator inhibitor-1 (PAI1), another member of the serpin superfamily and the major inhibitor of tPA in the circulatory system, prevents $\mathrm{HI}$-induced brain injury (Yang et al., 2009). However, the ubiquitously expressed character of PAI-1 limits its use in the CNS. In contrast, the brain tissuespecific expression characteristic of neuroserpin provides an optimum candidate for the treatment of newborn HI injury. Consistent with these findings, our experiments show an increase in tPA expression and activity. The therapeutic administration of neuroserpin dramatically inhibits tPA activity and preserves cell viability. Unexpectedly, neuroserpin had no effect on neuronal tPA mRNA expression. This result goes against previous in vivo findings in which the inhibitor of the PA system decreased both tPA expression and activity (Adhami et al., 2008). Neuroserpin has been shown to reduce the tPA expression produced by microglial cells (Cinelli et al., 2001). Integrating this data with our results, we propose that neuroserpin has a cell-type specific effect on tPA expression.

The cerebral vascular developmental differences between preterm and term infants produce a variation of the vulnerable region caused by HI (Distefano and Pratico, 2010). Glucose is an obligate energy fuel for the brain, but the immature brain has a low capacity for glucose transport. The glucose transport limit initiates the cerebral energy failure during HI (Vannucci and Hagberg, 2004). Energy failure leads to depolarization of neurons and glia, intracellular calcium accumulation and increased levels of excitatory amino acids (EAAs), combined with excessive activation of NMDA receptors (Towfighi et al., 1997; Dirnagl et al., 1999). In the immature brain, NMDA receptors play important roles in long term potentiation (LTP), neuronal migration and synaptic pruning, containing subunits that allow the channel to be opened more easily for a longer period than in the adult. These developmental features make immature brains more susceptible to glutamate excitotoxic insults, which could be induced by an HI state (Johnston, 1995; Vannucci and Hagberg, 2004).

tPA has been shown to aggravate chronic NMDA-induced neuronal excitotoxicity with $24 \mathrm{~h}$ exposure to low concentration of NMDA (Nicole et al., 2001; Tsirka et al., 1995), and neuroserpin shows the ability to limit the exacerbation of the glutamatergic signaling stimulated by long-term exposure to NMDA (Lebeurrier et al., 2005). However, $2 \mathrm{~h}$ exposure to an OGD condition also induces an acute excitotoxic injury, where MK-801 protects neurons efficiently. To mimic this kind of acute excitotoxicity, we exposed neurons to $600 \mathrm{umol} / \mathrm{L}$ NMDA for $2 \mathrm{~h}$, which decreased cell viability to approximately $50 \%$. However, it is important to indicate that the exact extent of excitotoxicity during neonatal $\mathrm{HI}$ is still undefined, and we are undecided whether the acute excitatory model used in our studies reflects that seen in vivo. Previous research proves that acute NMDA toxicity is accompanied by autophagy induction and subsequent neuronal death (Sadasivan et al., 2010). In conjunction with this observation, our experiment also initiated a decrease of cell viability, a loss of neurons and an alteration of the neuronal morphology, which are detected by MAP2 expression. Although MAP2 marks the neuronal bodies and axons and its expression reflects the breakdown of neurites indirectly, the exact change of neurite length could not be measured. The administration of neuroserpin results in a more intact neuritic network and protects neurons against acute NMDA-induced excitotoxicity by restraining tPA activity ex vivo.

However, tPA has been shown to rescue neurons from apoptosis and to be a neuroprotective agent in the mouse hippocampus (Liot et al., 2006; Echeverry et al., 2010); neuroserpin is also capable of protecting neurons from ischemia-induced cell death independently of tPA inhibition (Wu et al., 2010). This differs from our result mainly because of the different types of experimental procedures, and it must be noted that neuroserpin actually exhibits tPA-independent roles in HI. Besides tPA, neuroserpin also reacts with UPA and plasmin. UPA is upregulated following ischemia (Adhami et al., 2008), while plasmin participates in the excitotoxic process (Tsirka et al., 1997). Neuroserpin has already been shown to abrogate the excitotoxic neuronal death induced by plasmin (Wu et al., 2010). Moreover, it is known that methionine residues constitute an important antioxidant defense mechanism (Levine et al., 1996). There are 20 methionine residues contained in the neuroserpin molecular structure, which partly explains the oxidative tolerance produced by neuroserpin, and constitutes neuroserpin's neuroprotective effects against the oxidative stress condition during HI (Mohsenifar et al., 2007). In addition, systemic inflammatory stimulus is detrimental to $\mathrm{HI}$ and neuroserpin is reported to possess anti-inflammatory activity by modifying Th cell responses and reducing plaque growth (MunuswamyRamanujam et al., 2010).

In conclusion, the currently available collaborative data support the idea that during HI, neuroserpin can display an age-related neuroprotective effect by restraining tPA-mediated neuroexcitotoxicity. A neuroserpin-based intervention seems to be an extremely promising future pathway for the successful treatment of neonatal hypoxic-ischemic encephalopathy. To develop a clinically feasible drug for neonatal hypoxicischemic encephalopathy, further in vivo studies are necessary.

\section{ACKNOWLEDGMENTS}

This work was supported by grants from the National Natural Science Foundation of China (No.30700908, No.30772343, and No.30973215). and the Program for Changjiang Scholars and Innovative Research Team in University, No. IRT0935. The authors would like to acknowledge Dr. Adam P. Allen for his editorial and review critique.

\section{REFERENCES}

ADHAMI F, YU D, YIN W, SCHLOEMER A, BURNS KA, LIAO G, DEGEN JL, CHEN J, KUAN CY (2008) Deleterious effects of plasminogen activators in neonatal cerebral hypoxia-ischemia. Am J Pathol 172:17041716. 
BENARROCH EE (2007) Tissue plasminogen activator: beyond thrombolysis. Neurology 69:799-802.

BERGER P, KOZLOV SV, CINELLI P, KRUGER SR, VOGT L, SONDEREGGER P (1999) Neuronal depolarization enhances the transcription of the neuronal serine protease inhibitor neuroserpin. Mol Cell Neurosci 14:455-467.

CINELLI P, MADANI R, TSUZUKI N, VALLET P, ARRAS M, ZHAO CN, OSTERWALDER T, RULICKE T, SONDEREGGER P (2001) Neuroserpin, a neuroprotective factor in focal ischemic stroke. Mol Cell Neurosci 18:443-457.

COLLEN D (2001) Ham-Wasserman lecture: role of the plasminogen system in fibrin-homeostasis and tissue remodeling. Hematology Am Soc Hematol Educ Program 2001:1-9.

DIRNAGL U, IADECOLA C, MOSKOWITZ MA (1999) Pathobiology of ischaemic stroke: an integrated view. Trends Neurosci 22:391-397.

DISTEFANO G, PRATICO AD (2010) Actualities on molecular pathogenesis and repairing processes of cerebral damage in perinatal hypoxicischemic encephalopathy. Ital J Pediatr 36:63.

ECHEVERRY R, WU J, HAILE WB, GUZMAN J, YEPES M (2010) Tissue-type plasminogen activator is a neuroprotectant in the mouse hippocampus. J Clin Invest 120:2194-2205.

FERRIERO DM (2004) Neonatal brain injury. N Engl J Med 351:1985-1995.

HARUKUNI I, BHARDWAJ A (2006) Mechanisms of brain injury after global cerebral ischemia. Neurol Clin 24:1-21.

JOHNSTON MV (1995) Neurotransmitters and vulnerability of the developing brain. Brain Dev 17:301-306.

LEBEURRIER N, LIOT G, LOPEZ-ATALAYA JP, ORSET C, FERNÁNDEZMONREAL M, SONDEREGGER P, ALI C, VIVIEN D (2005) The brain-specific tissue-type plasminogen activator inhibitor, neuroserpin, protects neurons against excitotoxicity both in vitro and in vivo. Mol Cell Neurosci 30:552-558.

LEVINE RL, MOSONI L, BERLETT BS, STADTMAN ER (1996) Methionine residues as endogenous antioxidants in proteins. Proc Natl Acad Sci USA 93:15036-15040.

LIOT G, ROUSSEL BD, LEBEURRIER N, BENCHENANE K, LÓPEZ -ATALAYA JP, VIVIEN D, ALI C (2006) Tissue-type plasminogen activator rescues neurones from serum deprivation-induced apoptosis through a mechanism independent of its proteolytic activity. J Neurochem 98:1458-1464.

MOHSENIFAR A, LOTFI AS, RANJBAR B, ALLAMEH A, ZAKER F, HASANI L, KIA BE, HASANNIA S (2007) A study of the oxidationinduced conformational and functional changes in neuroserpin. Iran Biomed J 11:41-46.

MUJSCE DJ, CHRISTENSEN MA, VANNUCCI RC (1990) Cerebral blood flow and edema in perinatal hypoxic-ischemic brain damage. Pediatr Res 27:450-453.

MUNUSWAMY-RAMANUJAM G, DAI E, LIU L, SHNABEL M, SUN YM, BARTEE M, LOMAS DA, LUCAS AR (2010) Neuroserpin, a thrombolytic serine protease inhibitor (serpin), blocks transplant vasculopathy with associated modification of T-helper cell subsets. Thromb Haemost 103:545-555.

NICOLE O, DOCAGNE F, ALI C, MARGAILL I, CARMELIET P, MACKENZIE ET, VIVIEN D, BUISSON A (2001) The proteolytic activity of tissue-plasminogen activator enhances NMDA receptor-mediated signaling. Nat Med 7:59-64.

OSTERWALDER T, CONTARTESE J, STOECKLI E, KUHN T, SONDEREGGER P (1996) Neuroserpin, an axonally secreted serine protease inhibitor. EMBO J 15:2944-2953.
QIAN Z, GILBERT ME, COLICOS MA, KANDEL ER, KUHL D (1993) Tissueplasminogen activator is induced as an immediate-early gene during seizure, kindling and long-term potentiation. Nature 361:453-457.

RODRÍGUEZ-GONZÁLEZ R, AGULLA J, PEREZ-MATO M, SOBRINO T, CASTILLO J (2011) Neuroprotective effect of neuroserpin in rat primary cortical cultures after oxygen and glucose deprivation and tPA. Neurochem Int 58:337-344.

RODRÍGUEZ-GONZÁLEZ R，SOBRINO T, RODRÍGUEZ-YÁÑEZ M MILLAN M, BREA D, MIRANDA E, MOLDES O, PÉREZ J, LOMAS DA, LEIRA R, DAVALOS A, CASTILLO J (2011) Association between neuroserpin and molecular markers of brain damage in patients with acute ischemic stroke. J Transl Med 9:58-65.

SADASIVAN S, ZHANG Z, LARNER SF, LIU MC, ZHENG W, KOBEISSY FH, HAYES RL, WANG KK (2010) Acute NMDA toxicity in cultured rat cerebellar granule neurons is accompanied by autophagy induction and late onset autophagic cell death phenotype. BMC Neurosci 11:21.

SHELDON RA, PARTRIDGE JC, FERRIERO DM (1992) Postischemic hyperglycemia is not protective to the neonatal rat brain. Ped Res 32:489-493.

TOWFIGHI J, MAUGER D, VANNUCCI RC, VANNUCCI SJ (1997) Influence of age on the cerebral lesions in an immature rat model of cerebral hypoxia-ischemia: a light microscopic study. Brain Res Dev Brain Res 100:149-160.

TSIRKA SE, GUALANDRIS A, AMARAL DG, STRICKLAND S (1995) Excitotoxin-induced neuronal degeneration and seizure are mediated by tissue plasminogen activator. Nature 377:340-344.

TSIRKA SE, BUGGE TH, DEGEN JL, STRICKLAND S (1997) Neuronal death in the central nervous system demonstrates a non-fibrin substrate for plasmin. Proc Natl Acad Sci USA 94:9779-9781.

VANNUCCI SJ, HAGBERG H (2004) Hypoxia-ischemia in the immature brain. J Exp Biol 207:3149-3154.

WANG YF, TSIRKA SE, STRICKLAND S, STIEG PE, SORIANO SG, LIPTON SA (1998) Tissue plasminogen activator (tPA) increases neuronal damage after focal cerebral ischemia in wild-type and tPA-deficient mice. Nat Med 4:228-231.

WU J, ECHEVERRY R, GUZMÁN J, YEPES M (2010) Neuroserpin protects neurons from ischemia-induced plasmin-mediated cell death independently of tissue-type plasminogen activator inhibition. Am J Pathol 177:2576-2584.

YANG D, NEMKUL N, SHEREEN A, JONE A, DUNN RS, LAWRENCE DA, LINDQUIST D, KUAN CY (2009) Therapeutic administration of plasminogen activator inhibitor-1 prevents hypoxic-ischemic brain injury in newborns. J Neurosci 29:8669-8674.

YEPES M, LAWRENCE DA (2004) Neuroserpin: a selective inhibitor of tissue-type plasminogen actovator in the central nervous syetem. Thromb Haemost 91:457-464.

YEPES M, SANDKVIST M, WONG MK, COLEMAN TA, SMITH E, COHAN SL, LAWRENCE DA (2000) Neuroserpin reduces cerebral infarct volume and protects neurons from ischemia-induced apoptosis. Blood 96:569576.

ZHANG L, QU Y, YANG C, TANG J, ZHANG X, MAO M, MU D, FERRIERO D (2009) Signaling pathway involved in hypoxia-inducible factor-1alpha regulation in hypoxic-ischemic cortical neurons in vitro. Neurosci Lett 461:1-6.

ZHANG Z, ZHANG L, YEPES M, JIANG Q, LI Q, ARNIEGO P, COLEMAN TA, LAWRENCE DA, CHOPP M (2002) Adjuvant treatment with neuroserpin increases the therapeutic window for tissue-type plasminogen activator administration in a rat model of embolic stroke. Circulation 106:740-745 